\title{
Streptococcus alpha growth in gingivitis patient's dental plaque after rinsing with green tea extract (Camellia sinensis)
}

\author{
Isti Endah Kurniwati, Juni Handajani, Regina TC. Tandelilin \\ Senior Secretariat, Faculty of Dentistry, Universitas Gadjah Mada \\ Department of Oral Biology, Faculty of Dentistry, Universitas Gadjah Mada
}

\section{ABSTRACT}

Green tea (Camellia sinensis) has been widely known as healthy drink since long time ago. One of the substances in green tea which can give health benefit is catechin, an antibacterial substance. The purpose of this research is to know the efficacy of rinsing with green tea extract to Streptococcus alpha growth on gingivitis patient's dental plaque. The research subjects include 30 mild gingivitis patients, and these subjects are divided into two groups: treatment group (20 patients) and control group (10 patients). Ten patients of treatment group rinse their mouth with $0.25 \%$ green tea extract and 10 other patients with $0.5 \%$ green tea extract. Meanwhile control group use Bactidol ( $0.1 \%$ Hexetidine). Rinsing the mouth is performed every morning and night for five days. Sampling is conducted on the first and sixth day. Before rinsing data is analyzed using ANAVA and the result shows a significant difference. ANAVA testing then is done using proportion value. ANAVA Testing result shows that there is no significant difference among the patients in treatment group. This result indicates that the effect of rinsing with $0.25 \%$ and $0.5 \%$ green tea extract is equivalent with the control $(0.1 \%$ Hexetidine $)$ to inhibit $\mathrm{S}$. alpha growth on mild gingivitis patient's dental plaque. From these two concentrations, it has not been known which one is the most effective concentration to inhibit $\mathrm{S}$. alpha growth on mild gingivitis patient.

Key words: Green tea (Camellia sinensis), Streptococcus alpha, mild gingivitis

\section{INTRODUCTION}

Dental plaque is a soft deposit in dentin surface consisting of various bacteria and microbial substances. Plaque is formed due to the piling of bacteria on acquired pellicle. Plaque mass consists of $70-80 \%$ bacteria and in $1 \mathrm{mg}$ plaque, there are 200-300 different species of bacteria. ${ }^{1}$

At first, Gram positive Streptococcus was found in plaque. ${ }^{2}$ Streptococcus alpha is a dominant bacteria in the early forming plaque, and will always be in the plaque. Streptococcus alpha is also called Streptococcus viridans, because it forms greenish color surrounding its colony. This bacterium does not play direct role in causing periodontal disease, but functions only in facilitating other bacteria colonization, including anaerobic bacteria, which plays an important role in causing periodontal disease. Streptococcus, however, also produces histolytic enzyme and toxic substances that can cause tissue damage. ${ }^{3}$

Streptococcus alpha has an important role in the increasing of other plaque bacteria colonization process. This bacterium facilitates the attachment 
of other bacteria in dental plaque, because it is able to form extracellular polysaccharides and can be a beneficial environment for the growth of other bacteria. ${ }^{4}$ This Streptococcus can attract the negative gram bacterial colonization and produce the acid which can damage the cells. ${ }^{5}$

If the plaque growth is ignored and the plaque is not cleaned, it will form a complex bacterial colony. The growth of plaque will cause gingivitis. ${ }^{6}$ The significance of plaque accumulation as the major cause of gingivitis had been reported by a Denmark researcher. He reported that in less than 14 days without cleaning the mouth, an excessive plaque accumulation will be formed in individual with healthy gingiva, thus will cause gingivitis. ${ }^{7}$ Various epidemiology studies also show that there is a positive relation between plaque score and gingivitis score. ${ }^{8}$

Gingivitis is an inflammatory reaction in the gingiva, as a response of bacteria accumulation and its product in gingival sulcus area. ${ }^{9}$ This gingival inflammation clinically causes bleeding; gingival color and contour alteration; swollen, reddish, shiny, and tender gingiva; papilla hypertrophy; and the increase of gingival crevice fluid flow. There are various factors, either local or systemic, which are the etiology of gingivitis. One of most important local etiologic factors frequently found is plaque bacteria accumulation on the dentin. ${ }^{10}$

The tendency to "back to nature" encourages people to use plants as antibacterial agent. Tea is often consumed as a drink because of its delicious taste, cheap price, and because it is easy to find. There are many kinds of tea based on its making process, i.e.: green tea, black tea, and oolong tea. Green tea is produced without fermentation process and has the most catechin content compared with other kinds of tea. ${ }^{11}$ Various studies have been conducted in order to know the special benefits of green tea. The special content of tea that is good for health is its flavanoid content called catechin. Catechin in green tea has antibacterial capability against Streptococcus alpha with the inhibitory concentration of minimum $0.5 \mathrm{mg} / \mathrm{ml}^{11}$

The similar in vitro study concludes that effective concentration of green tea in inhibiting Streptococcus alpha is $16 \%$, with minimum contact time of 1 minute. ${ }^{11}$ All kinds of tea extracts can inhibit the growth of Streptococcus mutans with a concentration between $0.625-2.5 \mathrm{mg} / \mathrm{ml}$, meanwhile for Indonesia green tea, minimum inhibitory concentration against Streptococcus mutans Ingbritt which is $1.25 \mathrm{mg} / \mathrm{ml}$ dan loose Streptococcus Sobrinus OMZ 176 is $2.5 \mathrm{mg} / \mathrm{ml} .^{12}$ Beside catechin, fluor content in tea is also able to inhibit Streptococcus mutans, so that the number of dental plaque is decreased..$^{13}$ Utilization of green tea extract with the concentration of $0.25 \%$ and $0.5 \%$ on gingivitis patient shows that the decrease of gingivitis severity marked by the declining of gingivitis index after rinsing the mouth for 5 days. ${ }^{14}$

Catechin as a phenol compound has the characteristics as disinfectant, antiseptic, bacteriostat and bacteriocide. ${ }^{11}$ Phenol can cause protein denaturation due to the damage of protein composition and alteration in the permeability of bacterial cells. ${ }^{15}$

Rinsing with mouth rinse is one of the methods to control dental plaque chemically in curing gingivitis. Rinsing with mouth rinse can decrease the amount of plaque bacteria and gingivitis, because mouth rinse can reach interproximal area and infiltrate subgingival area. ${ }^{6}$ In addition to its function as the inhibitor of bacterial colonization, mouth rinse also has mechanical effect of rinsing movement. When rinsing the mouth, cheek muscle will be moved, thus the mouth rinse will mechanically remove debris particles that consist of a lot of bacteria. ${ }^{16}$

Rinsing the mouth using green tea extract may inhibit the growth of Streptococcus alpha as early bacterial colony on the plaque, therefore can prevent the growth of plaque bacteria that can make gingivitis becomes more serious. The problem is, it has not been known how does the efficacy of rinsing with green tea extract to the growth of Streptococcus alpha on the gingivitis patient's dental plaque?

\section{MATERIAL AND METHOD}

This research uses Kepala Djenggot green tea. The making of green tea extract is done in Pusat Penelitian Obat Tradisional (PPOT) Universitas Gadjah Mada Yogyakarta. The making of green tea extract with the concentration of $0.25 \%$ and $0.5 \%$ is done by dissolving $250 \mathrm{mg}$ or $500 \mathrm{mg}$ green tea extract in aquabidest up to 100 $\mathrm{ml}$ volume. 
Research subjects include 30 mild gingivitis patients, and these subjects are divided into two groups: treatment group (20 patients) and control group (10 patients). Control group are given Bactidol $(0.1 \%$ Hexetidine) as positive control. Meanwhile treatment group are given green tea extract with the concentration of $0.25 \%$ and $0.5 \%$.

The selecting of research subjects is based on Gingival Index/GI by Loe and Sillness. In this research, the subjects selected are the patients with the score from 0.1 until 1.0 (mild gingivitis). ${ }^{10}$ Besides, there are other criteria for the subjects, i.e.: the subjects are not in menstrual period, do not have systemic disease, are not using drugs, are not using removable orthodontic and prosthetic equipments, are not allowed to eat and brush the tooth before the plaque sampling.

Plaque taking before the treatment is done by: the plaque is taken in the morning, before the subjects brush their teeth and eat, after fasting the day before (the subject are not allowed to eat, they are only allowed to drink mineral water). Before sampling, the score of dental plaque based on PHP index by Podshadley and Haley is determined. Plaque taking area is the dentin with the biggest score. The plaque is taken using curette. Curette edge is stratched on the dental buccal surface in the marginal area from distal to mesial. Plaque sample obtained after the subjects had fasting then at once put in the sterile reaction tube, and there had been $1 \mathrm{ml}$ physiological salt in the tube. If the plaque is not immediately processed on 4 hours after its taking, the tube should be kept with the temperature of $4^{\circ} \mathrm{C}$.

Subjects are instructed to rinse for five days using the mouth rinse given to them. They have to use $5 \mathrm{ml}$ mouth rinse for 1 minute in the morning and night before sleep, i.e.: immediately after brushing their teeth. After that, the subjects are not allowed to rinse their mouth using water.

The taking of second plaque sample is conducted on the sixth day, i.e.: before the subjects brush their teeth and eat. The method and the area of taking is the same is the taking of first plaque. In the last night of rinsing, subjects are not allowed to eat and can only drink mineral water after rinsing. Before the plaque is taking, $\mathrm{Gl}$ testing is done, and dental plaque score is also measured as done before.

The bacteria are identified by: vortex the tube with sample for 1 minute, then dilute sterile aquadest until dilution series of $10^{-6}$. From each sample, $10 \mu$ of it is taken, then planted in Petri dish consisting of blood agar media. Incubate for 24 hours in the temperature of $37^{\circ} \mathrm{C}$, then calculate the bacterial colony grown. If in the blood agar media there is bacteria with greenish zone surrounding it, 1-2 $\mathrm{mm}$ in diameter, there are lyses red cells, and a blurred border is formed outside the greenish zone, it can be identified as S. alpha colony. The amount of sample S. alpha is calculated by multiplying the number of bacterial colony and dilution series.

Dilution series: $X=$ The volume of cultured sample, $Y=$ Calculated colony amount, $K=$ The number of microbial: $\mathrm{Kx} 10 \times \mathrm{XxY} \mathrm{ml}=. . \mathrm{CFU} / \mathrm{ml}$.

\section{RESULT AND DISCUSSION}

The result of this research can be seen in Figure 1 . that describes $S$. alpha colony of plaque sample before and after treatment. The average of S. alpha amount (before and after rinsing) is indicated in Table 1, and the growth pattern can be seen in Figure 2.

Table I and Figure 2 shows that rinsing with $0.5 \%$ green tea extract will give more effect on decreasing of $\mathrm{S}$. alpha amount, compared with $0.25 \%$ green tea extract or positive control. This can be seen from the interval average of the biggest bacterial amount before and after rinsing with $0.5 \%$ green tea extract.

This decrease is possibly due to the antibacterial substance, catechin, which includes phenol or flavanoid group, consisted in green tea. Catechin is the most apparent ingredient in green tea composition. It composes $30 \%$ of the tea dry weight. ${ }^{18}$ Phenol and its derivatives cause protein denaturation, as a result of the damage of composition and the alteration in permeability of bacterial cell membrane. Bacterial cell membrane is composed of lipid and protein. ${ }^{15}$ Phenol breaks the three-dimension structure of protein leading to a random structure without any damage in the covalent structure. damaga in the covalent structure. It causes protein denaturation. ${ }^{19}$ 


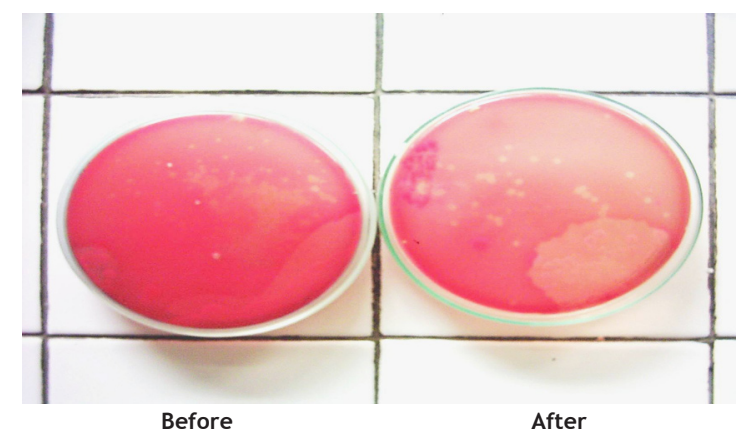

Figure 1. S. alpha colony from the plaque sample planted in blood agar before and after treatment

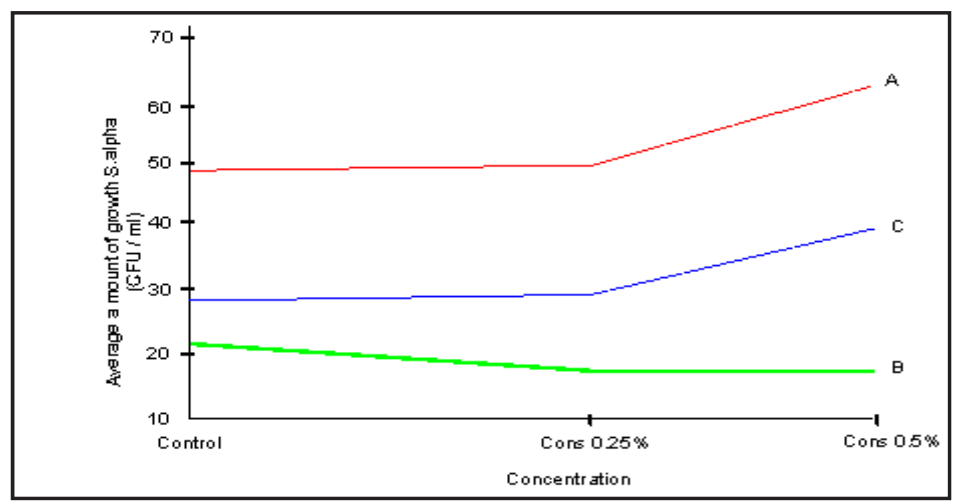

Figure 2. The pattern of $\mathrm{S}$. alpha growth average (CFU/ml) on the dental plaque with the concentration of $0.25 \%$ and $0.5 \%$ green tea extract. a. S. alpha amount before rinsing; b. S. alpha amount after rinsing; c. The interval of S. alpha amount before and after rinsing

Table 1. The average amount of $\mathrm{S}$. alpha growth (CFU/ml) on subject's dental plaque before and after rinsing the mouth and the interval

\begin{tabular}{cccc}
\hline & Before rinsing & After rinsing & Interval \\
\hline Control & $49,10.10^{6}$ & $21.04 .10^{6}$ & $28.06 .10^{6}$ \\
$0.25 \%$ green tea extract & $49.20 .10^{6}$ & $16.92 .10^{6}$ & $31.88 .10^{6}$ \\
$0.5 \%$ green tea extract & $65.80 .10^{6}$ & $17.83 .10^{6}$ & $47.97 .10^{6}$ \\
\hline
\end{tabular}

Table 2. S. alpha amount (CFU/ml) on dental plaque before rinsing

\begin{tabular}{cccccc}
\hline Source & db & JK & MK & F & P \\
& & & & & \\
\hline Between one group and other group & $2^{6}$ & 1.848 .200 .000 & 924.100 .000 & 3,191 & 0.057 \\
Among the member of the group & 7 & 7.818 .100 .000 & 289.559 .000 & & \\
Total & 29 & 9.666 .300 .00 & & & \\
\hline
\end{tabular}

Table 3. S. alpha amount (CFU/ml) on dental plaque before and after rinsing.

\begin{tabular}{|c|c|c|c|c|c|}
\hline Source & $d b$ & JK & MK & $\mathrm{F}$ & $p$ \\
\hline $\begin{array}{c}\text { Between one group and other group } \\
\text { Among the member of the group } \\
\text { Total }\end{array}$ & $\begin{array}{l}2^{6} \\
7 \\
29\end{array}$ & $\begin{array}{c}589.674 .000 \\
5.267 .849 .000 \\
5.837 .523 .000\end{array}$ & $\begin{array}{l}284.837 .000 \\
195.106 .000\end{array}$ & 1.460 & 0.250 \\
\hline
\end{tabular}

Because the bacterial cell membrane protein is denatured, the bacterial cell membrane and its function will also be damaged. With the lost of bacterial cell membrane activities, phenol will easily enter the cell, therefore the protein and nucleic acid in bacterial cell membrane will be denatured. ${ }^{11}$ Protein and nucleic acid molecules is plays important role in the survival of a cell, 
so protein and nucleic acid denaturation will cause cell lyses, and bacterium will finally die. ${ }^{20}$ In addition, the damage of cell membrane cause protoplast is formed from positive gram organism, or spheroplast is formed from negative gram organism, and this form is only bordered by cytoplasmic membrane. Protoplast or spheroplast is so sensitive of osmotic pressure. ${ }^{21}$ If the bacteria are not able to manage the difference of osmotic pressure, so the bacteria will die. ${ }^{20}$

The declination of bacteria amount in this research is supported by previous studies, which shows that green tea extract can inhibit the growth of S. alpha bacteria, thus this green tea extract can be used as mouth rinse. Plaque control chemically using antimicrobial mouth rinse can reduce or inhibit bacterial colonization on dental surface. ${ }^{22}$ Beside the bacteriological effect, mouth rinse has also mechanical effect of the rinsing movement. While rinsing, cheek muscles will also move, thus the mouth rinse will mechanically remove the debris particles consisting a lot of bacteria. ${ }^{16}$

The result of Variance homogeneity testing from resulting $S$. alpha amount shows that the three groups of treatment have the same variance, because they show significance $(p=0.309)$, thus ANAVA testing then can be done, and the result is summarized in Table 2.

Table 2 shows that there is a significant difference of S. alpha amount before rinsing, so that ANAVA testing can be done using proportion value of bacterial amount decreasing. From the data of proportion value, it is known that the data is in the range value of $30-70 \% .{ }^{17}$ ANAVA one line testing result of proportion value is presented in Table 3.

Table 3 shows that there is no significant difference between the concentration of green tea extract and control of $S$. alpha growth. It means that green tea extract mouth rinse with the concentration of $0.25 \%, 0.5 \%$ and control $(0.1 \%$ hexetidine) give the same effect in inhibition of S. alpha growth.

In this research, $0.25 \%$ green tea extract has indicated the ability in inhibiting $\mathrm{S}$. alpha. Catechin from green tea has antibacterial ability against $\mathrm{S}$. alpha with minimum inhibitory concentration is $0.5 \mathrm{mg} / \mathrm{ml} .{ }^{11}$ It has been proven in vitro that all kinds of green tea extracts can inhibit Streptococcus mutans growth with the concentration of $0.625-2.5 \% .12$

Green tea extract of $0.5 \%$ shows the greater ability in suppressing the growth of $\mathrm{S}$. alpha compared with other concentration, as can be seen in the biggest interval (Table 1). This indicates that the concentration difference of green tea extract has different ability in inhibiting S. alpha growth. The higher the concentration, the more antibacterial material dissolved, so that the more bacteria killed. ${ }^{12}$ Therefore, the higher the green tea extract concentration, the higher antibacterial potent. This is in line withe to the statement of Pelczar and Chan, that the factors affected an antimicrobial work are concentration, target contact period, temperature, species, and organic material. ${ }^{20}$

Because of the researcher's limitation, this research has not known the most effective maximum concentration. As known before, high concentration has particular limit in order to be able to inhibit bacterial growth. After reaching the optimum point, the effect of a drug will decline. ${ }^{24}$ Complex plaque bacteria is initial factor that can cause periodontal disease. Therefore, it should be prevented by the effort of inhibition bacterial further growth, especially $S$. alpha, because it is the most dominant bacterium in the early formation of supragingival plaque. By preventing the growth of S. alpha, it means that we prevent the formation of subgingival plaque, which can cause periodontal disease. Minimum inhibitory concentration is the minimum concentrations of a substance that can in vitro inhibit biological activities of the bacteria. In the oral cavity, there is saliva that can decline a solution's concentration, so the mouth rinse concentration should be folded minimum 4 -fold from minimum inhibitory concentration, so it can be effectively used as rinse material. ${ }^{11}$

The less significant difference between the concentration of $0.25 \%$ and $0.5 \%$, and the control in inhibiting $\mathrm{S}$. alpha is possibly due to this saliva effect. Besides, it should be known that $\mathrm{S}$. alpha consists of some bacterial species. Either the composition or the amount of bacteria in dental plaque is varied, depends on the difference of plaque formation starting time (Plaque's age), location, dietary rules and kinds of food, and also life style in keeping of dental and oral health. ${ }^{8}$ It also has been known that: knowing the effect of an antimicrobial drug in oral cavity, which is done 
in vivo, is affected by many factors affecting oral cavity. These factors can change immediately and can be different for each individual. ${ }^{25}$

There are many factors affecting this research's result. Subject obedience in using mouth rinse can possibly affect the result. In addition, daily diet, subject's life style in keeping dental and oral health that can not be controlled, and also the errors of bacteriological procedures can be the causes of errors in this research.

\section{CONCLUSION}

Rinsing the mouth using green tea extract can decrease the amount of $\mathrm{S}$. alpha in the gingivitis patient's dental plaque. The influence of $0.25 \%$ green tea extract and $0.5 \%$ green tea extract, and $0,1 \%$ hexetidine will give the same effect in inhibiting the growth of S. alpha in mild gingivitis patient's dental plaque.

\section{REFFERENCES}

1. Ramfjord SP, Ash MM. Periodontology and periodontics modern theory and practice. St. Louis: Ishiyaku Euroamerica Inc.; 1989. p. 669.

2. Prayitno SW. Gingivitis. Jakarta: Proceeding Forum Ilmiah II Faculty of Dentistry Universitas Trisakti; 1987. p. 25-31.

3. Michalek SM, Mc Ghee JR. Streptococcus with emphasis on streptococcus mutans. In: Mc Ghee Jr. Dental microbiology. Philadelphia: Harper and Row Publisher; 1982. p. 685-6.

4. Carranza FA. Glickman's clinical periodontology, $7^{\text {th }}$ ed. Philadelphia: WB. Saunders Co;1990. p. 387-99.

5. Newman MG, Sanz M, Nisengard RC, Haake SK. Host-bacteria interactions in periodontal diseases. In: Carranza FA (eds). Clinical periodontology. $8^{\text {th }}$ ed. Philadelphia: WB Saunders Co; 1996. p.121-8.

6. Soeroso Y. Perbedaan efek antara air garam hangat dan larutan $\mathrm{H}_{2} \mathrm{O}_{2} 3 \%$ sebagai obat kumur terhadap keradangan gingiva. Jakarta: Jurnal Kedokteran Gigi edisi khusus KPPIKG XI, Universitas Indonesia;1997. p. 237-9.

7. Houwink B, Dirks OB, Cramwinckel AB, Crielaers PJA, Dermault LR, Eijkmen MAJ, et al. $3^{\text {rd }}$ ed. Jakarta: EGC Penerbit Buku Kedokteran; 1993.
p. 162-71.

8. Herawati D. Pedoman kuliah: Mikrobiologi plak gigi penyebab penyakit periodontal. Yogyakarta: Universitas Gajah Mada; 1990. p. 38-58.

9. Prayitno SW. Kecenderungan pengelolaan penyakit periodontal di masa depan. Proceeding KPPIKG X. Jakarta: Universitas Indonesia; 1994. p. 69-70.

10. Carranza FA. Clinical features of gingivitis. In: Carranza FA (eds). Clinical periodontology. $8^{\text {th }}$ ed. Philadelphia: WB Saunders Co; 1996. p. 223-32.

11. Ismiyatin K. Konsentrasi minimal seduhan teh hijau Indonesia terhadap daya hambat pertumbuhan Streptococcus viridans. Maj Ked Gigi UNAIR 2000;34(2):52-5.

12. Tedjosasongko U, Kozai K, Hayashi F, Okada M, Nagasaka N. Anticariogenic potential of Indonesian tea. Proceeding TIMNAS I; 1998. p. 359-62.

13. Setijanto RD, Rahardjo MB, Sularso H, Hidajati $\mathrm{HE}$. daya hambat fluorida dalam minuman teh hitam terhadap pertumbuhan streptococcus mutans. Proceeding TIMNAS I; 1998. p. 301 06.

14. Handajani J, Asmara W, Tandelilin R. Efek ekstrak daun teh (CamelliaSinensis) Konsentrasi 0,5\% terhadap kadar slgA pada saliva penderita gingivitis: J Dentistry Indonesia 2004;11(1):1723.

15. Jawetz E, Melnick JL, Adelberg EA. Mikrobiologi untuk profesi kesehatan. $14^{\text {th }}$ ed. Jakarta: EGC; 1986. p. 239,242-3.

16. Hoag PM, Pawlak EA. Essential of periodontics, $4^{\text {th }}$ ed. Philadelphia: Mosby Co; 1990. p.14655.

17. Snedecor GW, Cochran WG. Statistical methods. $8^{\text {th }}$ ed. IOWA: IOWA State University Press; 1994. p. 273-98.

18. Oki AS. Pengaruh pemberian teh hijau (Camellia Sinensis) terhadap agregasi platelet. Proceeding Ceramah Singkat. Surabaya:FKG Unair; 1996. p. 925-7.

19. Dea H. Daun sirih sebagai antibakteri pasta gigi. 2003 [cited 2003 Sep 9]. Available from: http://www.kompas.com/iptek/news/ 2309/12/07486.htm.

20. Pelchzar MJ, Chan ECS. Jakarta: Penerbit Universitas Indonesia; 1988. p. 489-90. 
21. Greenwood D, Slack RCB, Peutherer JF. Medical microbiology a guide to microbial infections: pathogenesis, immunity, laboratory diagnosis and control. 14 $4^{\text {th }}$ ed. London: The English Language Book Society and Churchil Livingstone; 1992. p. 16-25.

22. Manson JD, Eley BM. Buku ajar periodonti. $2^{\text {nd }}$ ed. Jakarta: Hipocrates; 1993. p. 22-7.

23. Handajani J, Tandelilin R. Pengaruh daya anti bakteri ekstrak daun teh segar (Camellia Sinensis) terhadap Streptococcus alpha. J PDGI
2000; 50(2):14-21.

24. Eha D. Khasiat infusa daun kacapiring sebagai obat kumur terhadap keberadaan Candida albicans. Maj Ked Gigi UNAIR 1999:32(4):1569.

25. Adiastuti EP, Priyohadi. Pengaruh dosis serta lama terapi obat kumur tetrasiklin $\mathrm{HCl}$ terhadap jumlah koloni bakteri rongga mulut penderita stomatitis aftosa rekuren. Maj Ked Gigi UNAIR [Edisi khusus Foril V] 1996(2):91923. 